ENTREPRENEURSHIP AND SUSTAINABILITY ISSUES

ISSN 2345-0282 (online) http://jssidoi.org/jesi/ 2019 Volume 7 Number 1 (September)

http://doi.org/10.9770/jesi.2019.7.1(35)

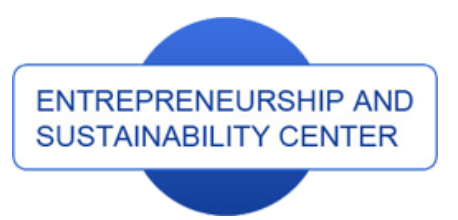

Publisher

http://jssidoi.org/esc/home

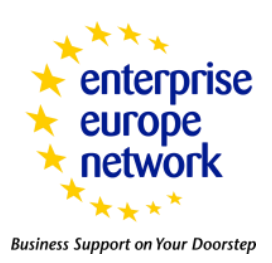

CASPA

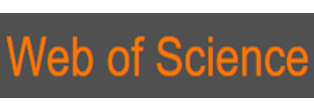

Clarivate
Analytics

\title{
EVALUATION OF REGIONAL INNOVATION SYSTEMS PERFORMANCE USING DATA ENVELOPMENT ANALYSIS (DEA)
}

\author{
Elena Vechkinzova ${ }^{1}$, Yelena Petrenko ${ }^{2,4}$, Stanislav Benčič ${ }^{3}$, Dmitriy Ulybyshev ${ }^{4,5}$, Yerlan Zhailauov ${ }^{4,5}$ \\ ${ }^{1}$ V.A. Trapeznikov Institute of Control Sciences of Russian Academy of Sciences, Profsoyuznaya Street, 65, 117997, Moscow \\ Russia \\ ${ }^{2}$ Plekhanov Russian University of Economic, 117997, Moscow, Stremyanny lane 36, Russia \\ ${ }^{3}$ Pan-European University, Tomášikova 20, 82102 Bratislava, Slovak Republic \\ ${ }^{4}$ Rational Solution ltd, Shakhtyorov Avenue, 23/7-10, 100026, Karaganda, Kazakhstan \\ ${ }^{5}$ Karaganda Economic University of Kazpotrebsoyuz, Akademicheskaya Street, 9, 100009, Karaganda, Kazakhstan \\ E-mails: ${ }^{1}$ kvin07@list.ru , ${ }^{2}$ petrenko_yelena@bk.ru, ${ }^{3}$ bencic7777@gmail.com, \\ ${ }^{4}$ d.n.ulybyshev@mail.ru, ${ }^{5}$ __invest@mail.ru
}

Received 16 March 2019; accepted 10 August 2019; published 30 September 2019

\begin{abstract}
Effective innovative systems testify to the success of regional economic policies. Based on the neoclassical approach novel approach towards evalution of regional innovation system functioning is suggested. In this study, the performance indicators of innovative systems in the regions of Kazakhstan are calculated using the non-parametric Data Envelopment Analysis (DEA) method for a convex model, with constant and variable effects of scale, focused on maximum outputs and minimum resource costs. The obtained results will facilitate providing recommendations for improving economic policy for the purposes of more efficient use of resources in regional innovation activities.
\end{abstract}

Keywords: regional innovation development, Kazakhstan, efficiency of innovation systems, non-parametric optimization, Data Envelopment Analysis (DEA).

Reference to this paper should be made as follows: Vechkinzova, E.; Petrenko, Y.; Benčič, S.; Ulybyshev, D.; Zhailauov, Y. 2019. Evaluation of regional innovation systems performance using Data Envelopment Analysis (DEA), Entrepreneurship and Sustainability Issues 7(1): 498-509. http://doi.org/10.9770/jesi.2019.7.1(35)

JEL Classifications: C01, C67, E22, G28, M00, O15, O5, O53; P4, P47 


\section{ENTREPRENEURSHIP AND SUSTAINABILITY ISSUES}

ISSN 2345-0282 (online) http://jssidoi.org/jesi/

2019 Volume 7 Number 1 (September)

http://doi.org/10.9770/jesi.2019.7.1(35)

\section{Introduction}

Innovation is a basis of any modern economy and in any country including the development of innovative ideas, the creation of innovative technologies, launching of innovative products and services. The innovative basis of the economy allows to compete on the inter-regional, central and global markets. The wealth of experience has been gained in creating innovation systems at the country level and alliances/collaborations at the regional level in countries with established market economies. The system of methods for analysing the effectiveness of innovation activities of both individual enterprises and the regions as a whole has been developed and various measures are used to increase the use of resources for creating innovation. The countries with new economies are in different situation. One of them is the Republic of Kazakhstan. Despite the fact that according to the data of the Kazakhstan Statistics Agency, the GDP forthe last 8 years has increased 2.4 times since 2010 and 2017 (or 243.41\%), and the growth in the volume of innovative products produced is almost 6 times (or 594.19) \%), the share of innovative products in the total volume of GDP has changed slightly from $0.65 \%$ to $1.59 \%$. This level of growth is not sufficient to achieve the goal set by the President of Kazakhstan: to enter in the top 50 countries with developed economies. There is potential for achieving the goal: there are about 500 deposits with 1225 kinds of minerals in the country. It is about Kazakhstan known, that 99 elements can be mined out of 126 periodic table elements. Currently, the economy of Kazakhstan has a predominantly commodity profile and the main task is to diversify the economy, transfer it to an innovative industrial profile. Considering the large territory (9th place in the world by area of the country) and low population density (average density of just over 6.72 people per 1 square $\mathrm{km}$ ), the role of regional centres is increasing not only as administrative centres, but also as centres of culture and innovation. The innovation of the region is the ability of the entire regional environment to adapt changes, as well as the presence of internal drivers of self-renewal of business processes and the generation of scientific and technical knowledge.

Sustainable development of the region and maintaining its competitiveness in the long term depends not only on resource capabilities (the so-called factors of the first nature), but on agglomeration effects, modernization and informatization processes, human capital (that is, factors of the second nature).

Unlike natural resources, the distribution of which across regions is impossible to change, the formation of factors of a second nature of the desired quality is a controlled process. In this regard, it is relevant to study the level of innovative development of the regions of Kazakhstan, the analysis of the effectiveness of the formation and functioning of the factors of innovative activity of the regions.

Efficiency is a complex property of any purposeful activity which shows the degree of achievement of the goal, taking into account the costs and time resources. To measure the effectiveness of the correlate the results obtained with the costs incurred. Usually, when analysing economic efficiency, traditional profitability indicators are used. However, this information is not enough for an objective assessment of how efficiently certain types of resources are used, how much the resource potential has been exhausted in various regions, how rational resource provision can affect the final results of innovation activities. Based on this, the present study uses the neoclassical approach within the framework of the concept proposed by Farrell (1957), which explicitly or implicitly underlies the majority of work on economic efficiency, to assess the efficiency of using certain types of resources. In particular, it examines the technical efficiency of the use of production resources.

The purpose of the research is to determine the level of regional innovation development, evaluation the effectiveness of existing regional innovation systems and provide recommendations for improving economic policy for the purposes of optimal use of resources in regional innovation activities. 


\section{ENTREPRENEURSHIP AND SUSTAINABILITY ISSUES}

ISSN 2345-0282 (online) http://jssidoi.org/jesi/

2019 Volume 7 Number 1 (September)

http://doi.org/10.9770/jesi.2019.7.1(35)

Methods of the research, in the process of the research, statistical methods of processing economic data, were used as well as Data Envelopment Analysis (DEA).

\section{Methodical approaches}

The concept of technical efficiency in the use of production resources implies a comparison of objects (decision making units, DMU) according to the degree of their use of their resources. The best are taken as "reference", ensuring maximum output of products per resource unit. In our understanding, the most simple and clear methodological tools for determining technical efficiency were proposed in 1978 in their article by American scientists A. Charnes, W. W. Cooper, E. Rhodes (Charnes, A., Cooper, W. W., Rhodes, E. 1978. Measuring the efficiency of Decision Making Units, European journal of operational research, Vol. 2: 429-444), which saves us from having to give detailed methodological calculations, limited only by the most necessary explanations.

In science and research of developed countries, the Data Envelopment Analysis (DEA) method is quite well known and is used by such authors as Malmquist (1953), Farrel (1957), Sueyoshi T. (1992), Färe et al. (1994), Chung Y.H., Cooper W., Seiford L., Tone K. (2007), Karimzadeh M. (2012), Bian Y., He P., Xu H. (2013). Carrillo M., Jorge J.M. (2016) and others. On the territory of the CIS countries, this method is not so well known and is used by Russian scientists mainly to assess the effectiveness in the banking sector - Arshinova T. (2011), Teplova T.V., Sokolova T.V. (2017), in agriculture- Serova E.V., Grazdaninova M.P., Karlova N.A. (2003), Sazonov, S. and Sazonova, D. (2005), Tillak P., Epstein D. (2003), in environmental management - Ratner S.V., Ratner M.D. (2017), Ratner S.V., Iosifov V.V. (2018), in the analysis of socio-economic systems - Morgunov E.P. (2007), Piskunov A.A. (2008), Krivonozhko V.E. (2010).

In this research, the performance indicators of innovative systems in the regions of Kazakhstan are calculated using the non-parametric Data Envelopment Analysis (DEA) method for a convex model, with constant and variable effects of scale, focused on maximum output and minimum resource costs.

There are a number of objects (DMU) - in our case, the regions of Kazakhstan, each of which is described by a set of inputs and outputs (resources and outputs). They are homogeneous in this respect.

Inputs are resources consumed by objects (in a general sense, what actors seek to reduce);

Outputs are the outputs produced (in a general sense, what actors seek to increase);

Efficiency - the ratio of inputs to outputs.

The system is represented as a black box (that is, the internal structure of the interconnections between inputs and outputs, the parameters of these interconnections are unknown). The solution consists in finding the most efficient objects and defining model (reference) objects and parameters for inefficient ones.

The essence of this method is as follows. Figure 1 shows the set of DMUs: P1, P2, P3, P4, P5, P6, which, using the same resource $\mathrm{X}$, produce the product $\mathrm{Y}$. The return of the resource for each DMU is determined by the ratio $\mathrm{Yi} / \mathrm{Xi}$. DMU P2 has the greatest return on the resource.

If, with an increase in the amount of the resource, its return in the reference DMUs does not decrease, then the reference DMUs will be on the OP2 line. This line is the border of production capabilities with a constant effect of scale - CRS (Constant Returns to Scale): if the input parameters change proportionally, the output parameters will change in the same proportion. But if, with an increase in the amount of a resource, its return changes, then the border between the P1, P2, P3, P4 points will act as the boundary of the production capabilities — the line on which the reference DMUs lie (point P1 corresponds to the regions with the least amount of resources). Capacity 
with variable scale effect - VRS. This curve is the limit of production (Variable Returns to Scale). The technical effectiveness of DMUs lying on the shell (the boundary of production capabilities) is equal to one.

For DMU P5, which is under the envelope curve, the technical efficiency scores are determined as follows:

- net (local) efficiency is technical efficiency with a variable effect of scale, oriented maximum outputs (performance) - TEV0 $=$ KP5 / KL or oriented minimum inputs (resources) - TEVI = AC / AP5. Net (local) technical efficiency reflects the efficiency of the DMU (quality of business processes);

- total (global) efficiency is technical efficiency with a constant scale effect TEC $=$ KP5 / KM;

- scale efficiency $=$ total efficiency / net efficiency. Scale efficiency reflects the adverse conditions in which the DMU operates.

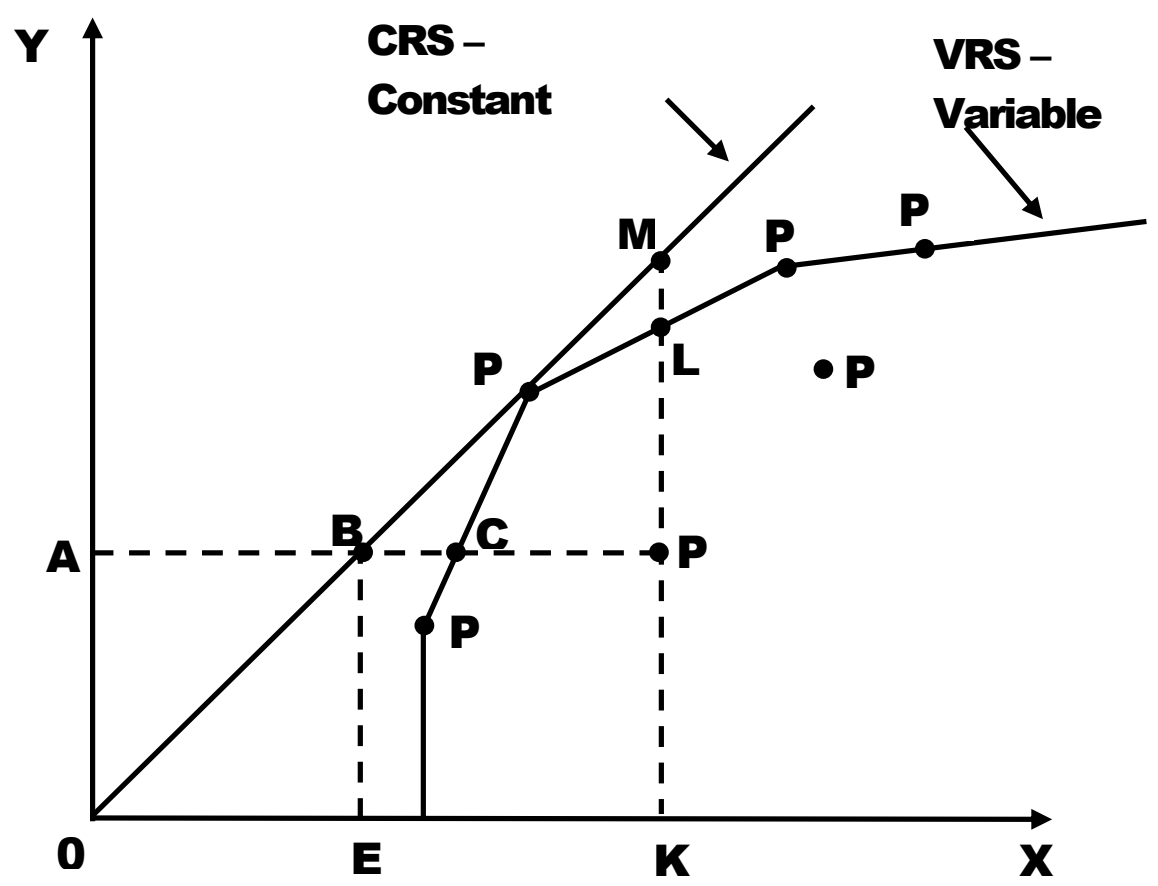

Fig. 1. Graphical interpretation of the DEA method

Source: drawn by authors

To understand the differences in the types of technical efficiency given above, it is necessary to take into account that efficiency is a complex property of any purposeful activity that manifests itself only in the process of the system functioning and reflects the degree of suitability of the system for its use for its intended purpose. In our case, we consider regional innovation systems as a system, and the intended purpose is to increase the level of innovation development (innovation) of the region.

The effectiveness of the system is determined by factors that can be divided into:

- internal factors characterizing net or local efficiency - quality of management, quality of business processes functioning, quality of resources used; 
- external factors that characterize the overall or global efficiency - the structure of the system, the technology used functioning;

- environmental factors characterizing the effectiveness of scale - conditions of the system's functioning: geographical location, climatic conditions, legislative, budgetary and tax restrictions, etc.

Thus, depending on the obtained results of the calculation according to the DEA methodology, it is possible to localize the problem area of the functioning system (region, DMU) and develop targeted measures to eliminate or level out negative factors affecting the efficiency of the system (DMU).

There are also other attractive properties of the DEA method:

- allows to calculate one aggregated - scalar - indicator for each object;

- can simultaneously process many inputs and many outputs, each of which can be measured in different units of measure;

- allows to take into account external variables in relation to the system under consideration - environmental factors;

- does not require an priori indication of weights for variables corresponding to the input and output parameters when solving the optimization problem;

- does not impose any restrictions on the functional form of the relationship between inputs and outputs;

- allows, if necessary, to take into account the preferences of managers regarding the importance of certain input or output variables;

- makes specific assessments of the desired changes in the inputs / outputs that would allow the inefficient objects to be brought to the efficiency margin;

- forms the Pareto-optimal set of points corresponding to efficient objects;

- focuses on identifying examples of so-called best practice (best practice), and not on any average trends, such as regression analysis.

\section{DEA method limitations}

This method does not contain restrictions related to the functional form of the model, the only requirement of the DEA-models is that all the results obtained fall either on or below the effective boundary. Otherwise, the researcher will face mixed, rather than technical efficiency, an element of which will be structural inefficiency (that is, with a given structure and the proportions of input resources, this sampling unit cannot achieve efficiency).

The specificity of the DEA method is that it is illegal to compare the results by time series, that is, it is impossible to identify the trend in DMU performance indicators by years, but it is possible to compare the values of indicators for different DMUs in a fixed year. This limitation is due to the method of DEA-simulation, namely the pairwise comparison of each DMU with each other, which shows that the evaluation of DMU effectivity may be different in different periods are not due to the fact that DMU optimized or worsened his attitude "output - input", but because of the fact other DMU changed their "output - input".

\section{Main results of the research}

For the calculation in this study, the publicly available version of the DEAP program was used (http://www.uq.edu.au/economics/cepa/deap.php ).

Evaluation of the effectiveness of the innovation system of the regions of Kazakhstan included evaluation for 4 inputs and 4 outputs. The actual values of the indicators are given in table 1. 
ENTREPRENEURSHIP AND SUSTAINABILITY ISSUES

ISSN 2345-0282 (online) http://jssidoi.org/jesi/ 2019 Volume 7 Number 1 (September) http://doi.org/10.9770/jesi.2019.7.1(35)

Table 1. Baseline data for 2017 regions of Kazakhstan

\begin{tabular}{|c|c|c|c|c|c|c|c|c|}
\hline \multirow{3}{*}{$\begin{array}{l}\text { Regions } \\
\text { (administrative } \\
\text { areas) of } \\
\text { Kazakhstan }\end{array}$} & \multicolumn{4}{|c|}{ Resources (Model inputs) } & \multicolumn{4}{|c|}{ Results (Model outputs) } \\
\hline & $\begin{array}{l}\text { Number of } \\
\text { R \& D } \\
\text { employees, } \\
\text { person }\end{array}$ & $\begin{array}{l}\mathrm{R} \& \mathrm{D} \text { and } \\
\text { innovation } \\
\text { costs, mln. } \\
\text { tenge }\end{array}$ & $\begin{array}{c}\text { Number of } \\
\text { organizations } \\
\text { performing } \\
\text { R \& D units }\end{array}$ & $\begin{array}{c}\text { Number of } \\
\text { innovation } \\
\text { infrastructure, } \\
\text { units }\end{array}$ & $\begin{array}{c}\text { Number of } \\
\text { issued security } \\
\text { documents, } \\
\text { units }\end{array}$ & $\begin{array}{c}\text { Number of } \\
\text { enterprises } \\
\text { using new } \\
\text { technologies, } \\
\text { units }\end{array}$ & $\begin{array}{l}\text { Number of new } \\
\text { technologies } \\
\text { and equipment } \\
\text { used, units }\end{array}$ & $\begin{array}{l}\text { Volume of } \\
\text { innovative } \\
\text { products } \\
\text { produced, } \\
\text { mln. tenge }\end{array}$ \\
\hline & input1 & input2 & input3 & input4 & output 1 & output 2 & output3 & output4 \\
\hline Akmola & 678 & 38074,0 & 11 & 3 & 88 & 38 & 147 & 15721,9 \\
\hline Aktobe & 362 & 57900,3 & 16 & 5 & 102 & 60 & 130 & 39442,0 \\
\hline Almaty & 968 & 9923,0 & 11 & 4 & 272 & 15 & 45 & 12624,2 \\
\hline Atyrau & 474 & 145345,6 & 10 & 5 & 49 & 71 & 111 & 5768,0 \\
\hline West Kazakhstan & 323 & 6855,3 & 8 & 9 & 61 & 8 & 12 & 18122,1 \\
\hline Zhambylskaya & 377 & 13588,3 & 11 & 3 & 113 & 12 & 127 & 50854,7 \\
\hline Karaganda & 1360 & 32208,5 & 29 & 9 & 335 & 35 & 65 & 32048,0 \\
\hline Kostanay & 569 & 37098,0 & 14 & 2 & 82 & 114 & 362 & 91502,6 \\
\hline Kyzylorda & 229 & 6592,7 & 8 & 3 & 51 & 31 & 64 & 5505,8 \\
\hline Mangystau & 696 & 13716,5 & 6 & 5 & 37 & 5 & 15 & 294,9 \\
\hline $\begin{array}{l}\text { South } \\
\text { Kazakhstan }\end{array}$ & 1090 & 188446,8 & 19 & 8 & 338 & 34 & 505 & 125231,6 \\
\hline Pavlodar & 654 & 111188,1 & 11 & 7 & 138 & 24 & 128 & 177881,5 \\
\hline $\begin{array}{l}\text { North } \\
\text { Kazakhstan }\end{array}$ & 93 & 21744,6 & 5 & 5 & 121 & 15 & 547 & 13804,9 \\
\hline East Kazakhstan & 2325 & 106347,6 & 34 & 11 & 160 & 44 & 147 & 80472,0 \\
\hline Astanacity & 3062 & 109231,6 & 62 & 40 & 778 & 36 & 1258 & 149277,5 \\
\hline Almaty city & 8821 & 77854,3 & 131 & 27 & 2317 & 162 & 1628 & 26183,3 \\
\hline
\end{tabular}

Source: compiled by the authors based on the results of DEA analysis

The results of the calculations of the input-oriented model are given in Table 2. Recall that the goal of the inputoriented model is to minimize the input parameters, while the output parameters must either remain at the initial level or increase.

Table 2. The results of the calculation of the model with a focus on input for the regions of Kazakhstan

\begin{tabular}{|c|c|c|c|c|c|c|}
\hline \multirow{2}{*}{$\begin{array}{l}\text { Regions } \\
\text { (administrative areas) } \\
\text { of Kazakhstan }\end{array}$} & \multicolumn{2}{|c|}{ CRS (Constant Returns to Scale) } & \multicolumn{2}{|c|}{ VRS (Variable Returns to Scale) } & \multicolumn{2}{|c|}{ Scale efficiency } \\
\hline & value & $\begin{array}{c}\begin{array}{c}\text { Conclusion on } \\
\text { overall / global } \\
\text { efficiency }\end{array} \\
\end{array}$ & value & $\begin{array}{c}\text { Clean / Local } \\
\text { Performance } \\
\text { Conclusion } \\
\end{array}$ & value & $\begin{array}{c}\text { Conclusion on } \\
\text { Scale } \\
\text { Efficiency } \\
\end{array}$ \\
\hline Akmola & 0,612 & ineffective & 0,935 & ineffective & 0,654 & ineffective \\
\hline Aktobe & 0,854 & ineffective & 0,854 & ineffective & 0,999 & ineffective \\
\hline Almaty & 1 & effective & 1 & effective & 1 & effective \\
\hline Atyrau & 0,872 & ineffective & 1 & effective & 0,872 & ineffective \\
\hline West Kazakhstan & 0,845 & ineffective & 1 & effective & 0,845 & ineffective \\
\hline Zhambylskaya & 1 & effective & 1 & effective & 1 & effective \\
\hline Karaganda & 0,774 & ineffective & 1 & effective & 0,774 & ineffective \\
\hline Kostanay & 1 & effective & 1 & effective & 1 & effective \\
\hline Kyzylorda & 1 & effective & 1 & effective & 1 & effective \\
\hline Mangystau & 0,285 & ineffective & 1 & effective & 0,285 & ineffective \\
\hline South Kazakhstan & 1 & effective & 1 & effective & 1 & effective \\
\hline Pavlodar & 1 & effective & 1 & effective & 1 & effective \\
\hline
\end{tabular}


ENTREPRENEURSHIP AND SUSTAINABILITY ISSUES

ISSN 2345-0282 (online) http://jssidoi.org/jesi/ 2019 Volume 7 Number 1 (September) http://doi.org/10.9770/jesi.2019.7.1(35)

\begin{tabular}{|l|l|l|l|l|l|l|}
\hline North Kazakhstan & 1 & effective & 1 & effective & 1 & effective \\
\hline East Kazakhstan & 1 & effective & 1 & effective & 1 & effective \\
\hline Astanacity & 1 & effective & 1 & effective & 1 & effective \\
\hline Almaty city & 1 & effective & 1 & effective & 1 & effective \\
\hline Main & 0,890125 & & 0,9868125 & & 0,901825 & \\
\hline
\end{tabular}

Source: compiled by the authors based on the results of DEA analysis

The model with constant returns to scale is more stringent and imposes serious additional restrictions. It is natural that the average value of technical efficiency, calculated by this model, equal to 0.89 , is significantly lower than that calculated by the variable effect of scale, which was 0.98 . The scale efficiency, which characterizes the ratio of efficiency, calculated by a constant effect of scale, to efficiency by a variable effect, is on average 0.9.

The share of innovation systems in the regions of Kazakhstan that formed an effective front ("reference" regions), with constant and variable scale effects, was, respectively, $63 \%$ and $88 \%$. Consequently, if we evaluate technical efficiency oriented at minimizing resource costs by a less rigid model (with a variable effect of scale), then we can assume that $12 \%$ or 2 regions can improve their performance by reducing resource costs.

Parameters of technical efficiency, focused on maximizing production (in our case - the results of innovation) are listed in Table. 3. The goal of the output-oriented model is to maximize the output parameters, while the input parameters should remain either at the initial level or decrease.

Table 3. The results of the calculation of the model with a focus on output for the regions of Kazakhstan

\begin{tabular}{|c|c|c|c|c|c|c|}
\hline \multirow[b]{2}{*}{$\begin{array}{l}\text { Regions (administrative } \\
\text { areas) of Kazakhstan }\end{array}$} & \multicolumn{2}{|c|}{ CRS (Constant Returns to Scale) } & \multicolumn{2}{|c|}{ VRS (Variable Returns to Scale) } & \multicolumn{2}{|c|}{ Scale efficiency } \\
\hline & value & $\begin{array}{c}\text { Conclusion on } \\
\text { overall / global } \\
\text { efficiency }\end{array}$ & value & \begin{tabular}{|c|} 
Clean / Local \\
Performance \\
Conclusion
\end{tabular} & value & \begin{tabular}{|c|}
$\begin{array}{c}\text { Conclusion on } \\
\text { Scale } \\
\text { Efficiency }\end{array}$ \\
\end{tabular} \\
\hline Akmola & 0,612 & ineffective & 0,694 & ineffective & 0,881 & ineffective \\
\hline Aktobe & 0,854 & ineffective & 0,94 & ineffective & 0,908 & ineffective \\
\hline Almaty & 1 & effective & 1 & effective & 1 & effective \\
\hline Atyrau & 0,872 & ineffective & 1 & effective & 0,872 & ineffective \\
\hline West Kazakhstan & 0,845 & ineffective & 1 & effective & 0,845 & ineffective \\
\hline Zhambylskaya & 1 & effective & 1 & effective & 1 & effective \\
\hline Karaganda & 0,774 & ineffective & 1 & effective & 0,774 & ineffective \\
\hline Kostanay & 1 & effective & 1 & effective & 1 & effective \\
\hline Kyzylorda & 1 & effective & 1 & effective & 1 & effective \\
\hline Mangystau & 0,285 & ineffective & 1 & effective & 0,285 & ineffective \\
\hline South Kazakhstan & 1 & effective & 1 & effective & 1 & effective \\
\hline Pavlodar & 1 & effective & 1 & effective & 1 & effective \\
\hline North Kazakhstan & 1 & effective & 1 & effective & 1 & effective \\
\hline East Kazakhstan & 1 & effective & 1 & effective & 1 & effective \\
\hline Astanacity & 1 & effective & 1 & effective & 1 & effective \\
\hline Almaty city & 1 & effective & 1 & effective & 1 & effective \\
\hline Main & 0,890125 & & 0,977125 & & 0,9103125 & \\
\hline
\end{tabular}

Source: compiled by the authors based on the results of DEA analysis

The value of technical efficiency, calculated by the constant effect of scale, when solving the problem on the maximum output of the results coincides with the value of this indicator, obtained by solving the problem, focused on the minimum resource costs, and is 0.89 . Given the proportional change in input and output parameters in the model with a constant effect of scale, the results of the calculation with a focus on the inputs and outputs will always be identical. The average value of technical efficiency, calculated from the variable scale effect, was 0.977 . 


\section{ENTREPRENEURSHIP AND SUSTAINABILITY ISSUES}

ISSN 2345-0282 (online) http://jssidoi.org/jesi/ 2019 Volume 7 Number 1 (September) http://doi.org/10.9770/jesi.2019.7.1(35)

The share of regions that have formed an effective front ("reference" regions), with a variable effect of scale, was $88 \%$. Therefore, it can be assumed that $12 \%$ or 2 regions can improve the performance of their activities by increasing the results of innovation activities.

\section{Discussion}

Evaluating the results, we note the following: the regions of Kazakhstan have significant reserves for improving the efficiency of innovation activities. For example, the average efficiency factors of using the production potential, determined for each of the three models, are respectively 0.89, 0.986 and 0.977 . At the same time, the scale efficiency was 0.9 for the minimum-oriented model, and 0.91 for the maximum-oriented model. This means that on average, the regions of Kazakhstan have realized their innovative potential by no more than $90 \%$ and $91 \%$, respectively.

When comparing the results of both models, it can be noted that the locally inefficient regions in both models are the same in the Akmola and Aktobe regions equally poor quality of the resources involved in innovation activity (expensive and / or low productive resources) and poor quality of business process management. In this situation, it is necessary to recommend reviewing the current structure and infrastructure of the regional innovation system, to consider the principles and management technologies in the reference regions.

According to the authors of the study, when developing recommendations for regional economic policy, it is necessary to rely on the results of the exit-oriented model. This choice is due to the fact that out of the four inputs (resources) considered, only one represents expenses in monetary form ( $\mathrm{R} \& \mathrm{D}$ costs), the other three resources are already existing objects (infrastructure facilities, research organizations, research teams), whose reduction only will increase social tensions in the regions. In this situation, it makes sense to set the task not to reduce resources, but to increase the efficiency and effectiveness of their functioning. When choosing between the models of CRS and VRS, one should prefer the variable of the model of VRS, since the relationship among numbers of researchers and the quality and volume of their work will be non-linear.

Based on these assumptions, we consider the recommended target values for two regions - Akmola and Aktobe regions (Tables 4 and 5).

Table 4. Recommended target values for Akmola region according to VRS model with exit orientation

\begin{tabular}{|l|l|l|l|l|}
\hline Variable & Original value & Radial movement & Slack movement & Projected value \\
\hline output 1 & 88.0 & 38.782 & 0.0 & 126.782 \\
\hline output 2 & 38.0 & 16.747 & 4.270 & 59.017 \\
\hline output 3 & 147.0 & 64.784 & 0.000 & 211.784 \\
\hline output 4 & 15721.9 & 6928.779 & 19863.457 & 42514.136 \\
\hline input 1 & 678.0 & 0.0 & -125.970 & 552.030 \\
\hline input 2 & 38074.0 & 0.0 & -17304.211 & 20769.789 \\
\hline input 3 & 11.0 & 0.0 & 0.0 & 11.0 \\
\hline input 4 & 3.0 & 0.0 & 0.0 & 3.0 \\
\hline
\end{tabular}

Source: compiled by the authors based on the results of DEA analysis

Despite the fact that we use a model with a focus on output, i.e. the goal is to obtain recommendations for increasing output indicators, in some cases to issue recommendations for reducing the values of input indicators. This is the case for inputs 1 (number of $R \& D$ workers) and 2 ( $R \& D$ and innovation costs). 
The standards for this region will be the North Kazakhstan (0.068), Kostanay (0.402) and Almaty (0.265) regions. In parentheses are the weights of the influence of the reference region to achieve the effectiveness of the region in question.

Table 5. Recommended target values for the Aktobe region according to the VRS model with exit orientation

\begin{tabular}{|l|l|l|l|l|}
\hline Variable & Original value & Radial movement & Slack movement & Projected value \\
\hline output 1 & 102.0 & 6.466 & 0.0 & 108.466 \\
\hline output 2 & 60.0 & 3.804 & 0.0 & 63.804 \\
\hline output 3 & 130.0 & 8.241 & 304.597 & 442.838 \\
\hline output 4 & 39442.0 & 2500.349 & 10231.853 & 52174.202 \\
\hline input 1 & 362.0 & 0.0 & 0.0 & 362.0 \\
\hline input 2 & 57900.3 & 0.0 & -28373.964 & 29526.336 \\
\hline input 3 & 16.0 & 0.0 & 0.0 & 16.0 \\
\hline input 4 & 5.0 & 0.0 & -1.334 & 3.666 \\
\hline
\end{tabular}

Source: compiled by the authors based on the results of DEA analysis

For the Aktobe region, as a result of the model calculation, recommendations were given not only to increase outputs, but also to reduce inputs 2 ( $\mathrm{R} \& \mathrm{D}$ and innovation costs) and 4 (innovation infrastructure facilities).

The standards for this region will be the North Kazakhstan (0.484), Karaganda (0.0288) regions and Almaty (0.0001). In parentheses are the weights of the influence of the reference region to achieve the effectiveness of the region under consideration.

Using the obtained target values of inputs and outputs, as well as having studied the experience of the reference regions, the regional administration and the local business community can develop a set of measures to enhance and increase the efficiency of innovation activities, which will not only increase the competitiveness of regions, but also as a result improve the quality of life of the population.

\section{Conclusions}

Currently, the economy of Kazakhstan has a predominantly commodity profile and the main task is to diversify the economy, transfer it to an innovative industrial profile. One of the ways is to increase the efficiency of regional innovation activities. Analysis of the efficiency of resource use and the effectiveness of innovation processes will help identify problem areas and formulate economic policy measures to increase the level of innovative development of the regions of Kazakhstan.

\section{References}

Farrell, M. J. 1957. The measurement of Productive efficiency. Journal of the Royal Statistical Society, Series A (General), 120(3): 253290. https://doi.org/10.2307/2343100

Charnes, A., Cooper, W. W., Rhodes, E. 1978. Measuring the efficiency of Decision Making Units, European Journal Of Operational Research, 2: 429-444. https://doi.org/10.1016/0377-2217(78)90138-8 


\section{ENTREPRENEURSHIP AND SUSTAINABILITY ISSUES}

ISSN 2345-0282 (online) http://jssidoi.org/jesi/ 2019 Volume 7 Number 1 (September) http://doi.org/10.9770/jesi.2019.7.1(35)

Cooper, W., Seiford, L., Tone, K. 2007. Data Envelopment Analysis. A Comprehensive Text with Models, Applications, References and DEA-Solver Software. 2nd Edition Published by Springer US. https://doi.org/10.1007/978-0-387-45283-8 ISBN 978-0-387-45281-4

Karimzadeh, M. 2012. Efficiency Analysis by Using Data Envelop Analysis Model: Evidence from Indian Banks. Int. Journal Latest Trends Fin. Econ, 2(3): 228-237.

Bian, Y., He, P., Xu, H. 2013. Estimation of potential energy saving and carbon dioxide emission reduction in China based on an ex-tended non-radial DEA approach. Energy Policy, 63: 962-971 https://doi.org/10.1016/j.enpol.2013.08.051

Carrillo, M., Jorge, J.M. 2016. A multiobjective DEA approach to ranking alternatives. Expert Systems with Applications, 50: 130-139. https://doi.org/10.1016/j.eswa.2015.12.022

Charnes, A., Cooper, W., Rhodes, E. 1981. Evaluating program and managerial efficiency: An application of data envelopment analysis to program follow through. Management Science, 27: 607-730. https://doi.org/10.1287/mnsc.27.6.668

Charnes, A., Cooper, W. W., Rhodes, E. 1978. Measuring the efficiency of Decision Making Units. European journal of operational research, 2: 429-444

Charnes, A., Clarke, C., Cooper, W., Golany B. 1984. A development study of DEA in measuring the effect of maintenance units in the U.S. Air Force. Annals of Operation Research, 2(1): 95-112. https://doi.org/10.1007/BF01874734

Chung, Y.H., Färe, R., Grosskopf, S. 1997. Productivity and undesirable outputs: A directional distance function approach. Journal of Environmental Management, 51(3): 229-240. https://doi.org/10.1006/jema.1997.0146

Cooper, W.W., Seiford, L.M., Tone, K. 2006. Introduction to Data Envelopment Analysis and its Uses, Published by Springer US. https://doi.org/10.1007/0-387-29122-9 ISBN 978-0-387-28580-1

DEAP program http://www.uq.edu.au/economics/cepa/deap.php

Färe, R., Grosskopf, S. Lovell C.A.K. 1994. Production Frontiers. - Published by Cambridge University Press. ISBN 978-0521072069, $382 \mathrm{p}$.

Färe, R., Grosskopf, S. 2004. Modelling undesirable factors in efficiency evaluation: comment. European Journal of Operational Research, 157: 242-245. https://doi.org/10.1016/S0377-2217(03)00191-7

Korhonen, P.J., Luptacik, M. 2004. Eco-efficiency analysis of power plants: An extension of data envelopment analysis. European Journal of Operational Research, 15: 437-446. https://doi.org/10.1016/S0377-2217(03)00180-2

Malmquist, S. 1953. Index numbers and indifference surfaces. Trabajos de Estatistica, 4(2): 209-242. https://doi.org/10.1007/BF03006863

Sueyoshi, T. 1992. Comparison and analyses of managerial efficiency and returns to scale of telecommunication enterprises by using DEA/WINDOW, Communications of the Operations Research Society of Japan, 37: 210-219.

Wang, K., Shiwei, Yu., Zhang, W. 2013. China's regional energy and environmental efficiency: A DEA window analysis based dynamic evaluation. Mathematical and Computer Modelling, 58(5-6): 1117-1127. https://doi.org/10.1016/j.mcm.2011.11.067

Wu, H., Shi, Y., Zhu, W. 2014. Effectiveness of the policy of circular economy in China: A DEA-based analysis for the period of 11th five-year-plan, Resources. Conservation and Recycling, 83: 163-175. https://doi.org/10.1016/j.resconrec.2013.10.003

Arshinova T. 2011. Construction of Equity Portfolio on the Basis of Data Envelopment Analysis Approach. Scientific Journal of Riga Technical University, 45. https://doi.org/10.2478/v10143-011-0050-1

Teplova, T.V., Sokolova, T.V. 2017. Nonparametric method of shell analysis for portfolio construction in the Russian bond market. Economics and mathematical methods, 53(3): 110-128. https://publications.hse.ru/articles/208456687

Serova, E.V., Grazhdaninova, M.P., Karlova, N.A. and others. 2003. Market purchased resources in Russian agriculture. IET Scientific Works No. 63R: 195 http://ecsocman.hse.ru/text/19190279/

Tillak, P., Epstein, D. 2003.Technical Efficiency of Agricultural Enterprises of the Leningrad Region. International Agricultural Journal, 4: 33-46; https://elibrary.ru/item.asp?id=21334493 


\section{ENTREPRENEURSHIP AND SUSTAINABILITY ISSUES}

ISSN 2345-0282 (online) http://jssidoi.org/jesi/ 2019 Volume 7 Number 1 (September)

http://doi.org/10.9770/jesi.2019.7.1(35)

Sazonov, S., Sazonova, D. 2005. Development of Peasant Farms in Central Russia. Comparative Economic Studies, 47(1): 101-114. https://doi.org/10.1057/palgrave.ces.8100079

Ratner S.V., Ratner M.D. 2017. Evaluation of the effectiveness of regional environmental management systems. Izvestia Volgograd State Technical University, 7 (202): 8-16. https://elibrary.ru/item.asp?id=30006922

Ratner, S.V., Iosifov, V.V. 2018. Assessment of the degree of compliance of the regional economic growth model with the principles of sustainable development using non-parametric optimization. Regional economy: theory and practice, 16(9-456): 1749-1765. https://doi.org/10.24891/re.16.9.1749

Piskunov, A.A., Ivanyuk, I.I., Danilina, E.P., Lychev, A.V., Krivonozhko, V.E. 2008. System rating regions using the methodology of the ASF. Bulletin AKSOR, 4: 24-30.

Krivonozhko, V.Ye., Lychev, A. V. 2010. Analysis of the activities of complex socio-economic systems. Moscow: Published by Publishing department of the faculty of the Moscow State University and Moscow State University. MAX Pres., 393p.

Krivonozhko, V.Ye., Propoi, A.I., Senkov, R.V., Rodchenkov, I.V., Anokhin P.M. 1999. Analysis of the performance of complex systems. Design automation, 1: 2-7.

Morgunov, E. 2007. Decision support system in the study of the effectiveness of complex systems: design principles, requirements and architecture. Bulletin of the Siberian State Aerospace University, 3(16): 59-63. https://cyberleninka.ru/article/v/sistema-podderzhkiprinyatiya-resheniy-pri-issledovanii-effektivnosti-slozhnyh-sistem-printsipy-razrabotki-trebovaniya-i-arhitektura 


\section{ENTREPRENEURSHIP AND SUSTAINABILITY ISSUES}

ISSN 2345-0282 (online) http://jssidoi.org/jesi/ 2019 Volume 7 Number 1 (September) http://doi.org/10.9770/jesi.2019.7.1(35)

Elena VECHKINZOVA PhD in Economics, Associate Professor, A.Trapeznikov Institute of Control Sciences of Russian Academy of Sciences, 117997, Moscow, Profsoyuznaya street, 65, Russia; +7 7015210205, +79655202615 . She is a member of the International Project Management Association (ICB IPMA-C). Research interests: economic and mathematical models and methods for managing the development of regions, innovation management, infrastructure, project and process management, monitoring and evaluation of programs and projects.

ORCID ID: 0000-0003-2543-625X

Yelena PETRENKO Doctor of economics, professor, Plekhanov Russian University of Economic, 117997, Moscow, Stremyanny lane 36, Russia;+77015143083 She is an expert of the European Bank for Reconstruction and Development in Kazakhstan. Research interests: strategic management, human resources management, sustainability of companies, entrepreneurship, marketing.

ORCHID ID: 0000-0001-6892-2392

Stanislav BENČIČ PhD, associate professor, Pan-European University, Tomášikova 20, 82102 Bratislava Slovak republic. Research interests: Comprehensive studies of regional development, intercultural communication in the economy, politics and international relations.

ORCID ID: 0000-0002-5753-1553

Dmitriy ULYBYSHEV PhD in Economics, Associate Professor, Rational Solution ltd, 100026, Karaganda, Shakhtyorov Avenue, 23/7-10, Kazakhstan; Karaganda Economic University of Kazpotrebsoyuz, 100009, Karaganda, Akademicheskaya street, 9, Kazakhstan.+77013183959. Research interests: innovative development of the economy of Kazakhstan, state regulation of the economy, regional social and economic systems, modern industrial policy, integrated development of territories, economic potential and structural policy.

ORCID ID: 0000-0003-3534-5992

Yerlan ZHAILAUOV PhD in Economics, Rational Solution ltd, 100026, Karaganda, Shakhtyorov Avenue, 23/7-10, Kazakhstan; Karaganda Economic University of Kazpotrebsoyuz, 100009, Karaganda, Akademicheskaya street, 9, Kazakhstan. Research interests: innovative development of the economy, regional socio-economic systems, the level and quality of life of the population, social infrastructure, economic potential and structural policy.

ORCID ID: 0000-0002-0609-6256

Register for an ORCID ID:

https://orcid.org/register

Copyright (C) 2019 by author(s) and VsI Entrepreneurship and Sustainability Center

This work is licensed under the Creative Commons Attribution International License (CC BY).

http://creativecommons.org/licenses/by/4.0/

CC) (i) Open Access 